\title{
Uji Resistensi Bakteri Vibrio parahaemolyticus Terhadap Ekstrak Makroalga Halimedadiscoidea, Halymenia dilatata dan Dictyota dichotoma
}

\section{Resistance Test of Vibrio Parahaemolyticus Toward Macroalgae Extract of Halymeda discoidea, Halymenia dilatata and Dictyota dichotoma}

\author{
Silvani Alfajri', Fenny Agustina ${ }^{1 *}$, Nurhaty Purnama Sari ${ }^{1}$, Pramuanggit PN $^{2}$ \\ ${ }^{1}$ Program Studi Pendidikan Biologi, FKIP, Universitas Riau Kepulauan, Batam \\ ${ }^{2}$ Balai Perikanan Budidaya Laut (BPBL) Setokok, Batam \\ *Koresponden: fennyagustina83@gmail.com
}

\begin{abstract}
Abstrak
Penelitian ini bertujuan untuk mengetahui resistensi bakteri Vibrio parahaemolyticus tehadap ekstrak makroalga Halymeda Discoidea, Halymenia Dilatata dan Dictyota dichotoma. Metode penelitian yang digunakan adalah eksperimental laboratoris, data dianalisa secara deskriptif. Penelitian dilakukan pada tanggal 26 Februari 2018 s/d 6 April 2018. Ekstraksi dilakukan dengan dua metode yaitu metode ekstrak basah dan metode maserasi. Metode Ekstrak basah dilakukan dengan cara mencampurkan 25 gr sampel dengan $25 \mathrm{ml}$ aquadest untuk konsentrasi 100\%. Sedangkan untuk konsentrasi 50\%, 25 gram sampel dicampurkan dengan 50 $\mathrm{ml}$ aquadest. Pada Metode Maserasi 5 gram sampel direndam dalam etanol absulute (98\%) sebanyak $50 \mathrm{ml}$ selama 2 x 24 jam pada inkubator shaker. Kemudian rendaman sampel dalam etanol diuapkan pada suhu ruang selama 30 jam atau sampai semua etanol menguap. Uji resistensi bakteri V. Parahaemoyticus dilakukan dengan metode difusi cakram dan diinkubasi selama 24 jam pada suhu $30^{\circ} \mathrm{C}$. Pengamatan dan pengukuran diamater zona bening dilakukan setiap 6 jam. Bakteri $V$. parahaemolyticus resisten terhadap ekstrak basah makroalga dengan konsentrasi $100 \%$ dan $50 \%$ karena zona bening (zona bebas bakteri) di sekitar kertas cakram tidak terbentuk. Bakteri $V$. parahaemolyticus sensitif terhadap ekstrak makroalga yang diekstraksi dengan metode maserasi, hal ini ditandai dengan terbentuknya zona bening di sekitar kertas cakram dengan rata-rata diameter 6,3 mm untuk H. Discoidea, $6 \mathrm{~mm}$ untuk H. Dilatata dan 6,6 mm untuk D.dichotoma. Kemampuan ekstrak makroalga yang diekstraksi dengan metode maserasi sebagai intibiotika alami dikategorikan "sedang".
\end{abstract}

Kata kunci: Bakteri, Makroalga, V. parahaemolyticus, Antibakteri, Maserasi

\begin{abstract}
This research aimed to find out resistance of Vibrio parahaemolyticus bacteria toward macroalgae extract of Halymeda Discoidea, Halymenia Dilatata and Dictyota dichotoma.Research method used experimental laboratory, data was analyzed descriptively. The research was conducted on February $26^{\text {th }} 2018$ to $6^{\text {th }}$ April 2018. Extraction was done with two methods which were wet extract method and maceration method. Method of wet extract was conducted by mixing 25 gt sample with $25 \mathrm{ml}$ aquadest for $100 \%$ concentration. Whereas for concentration 50\%, 25 gam of sample was mixed with $50 \mathrm{ml}$ aquadest. In maceration method, 5 gram of sample was soaked in ethanol absolute (98\%) of $50 \mathrm{ml}$ in for $2 \times 24$ hours in incubator shaker. Then sample immersion in ethanol was evaporated in room temperature for 30 hours or until all ethanol evaporated. Resistance test of $V$. Parahaemoyticusbacteria was resistance toward macroalgae extract which was extracted by maceration method. It was known by the formation of clear zone around paper disc with diameter average was $6.3 \mathrm{~mm}$ for H. Discoidea, $6 \mathrm{~mm}$ for H. Dilatata and $6.6 \mathrm{~mm}$ for D.dichotoma. The ability of microalgae extract which was extracted by maceration method as natural corebiotics was categorized "medium".
\end{abstract}

Keywords: Bacteria, Macroalgae, V. parahaemolyticus, Antibacteria, Maceration Method. 


\section{PENDAHULUAN}

Kepulauan Riau merupakan salah satu provinsi di Indonesia yang luas wilayahnya didominasi oleh periaran laut. Dengan kondisi demikian, tentunya Kepulauan Riau memiliki potensi bahari yang berlimpah. Seiring dengan berjalannya waktu, potensi kelautan Kepulauan Riau sudah dimanfaatkan oleh masyarakat sekitar. Dengan berlimpahnya kekayaan hayati perairan laut yang dimilliki Kepulauan Riau, tentunya tidak dapat dihindari interaksi antar berbagai macam organisme laut tersebut.

Interaksi organisme laut dengan lingkungannya tidak selamanya menguntungkan, beberapa kasus ada yang merugikan. Salah satu contoh adalah adanya serangan bakteri pada ikan-ikan tertentu. Jika ikan-ikan yang terinfeksi bakteri tersebut tidak mampu melawan serangan bakteri, maka akan timbul berbagai masalah bahkan ikan yang terinfeksi bisa mengalami kematian. Namun, dari studi literatur yang dilakukan, sejauh ini belum pernah ada laporan yang adanya kematian masal ikan di perairan laut Kepulauan Riau. Oleh sebab itu, penulis berasumsi bahwa ada beberapa spesies organisme laut yang berinteraksi dengan ikanikan terinfeksi bakteri tersebut diduga, mampu menghasilkan senyawa antibakteri.

Salah satu tumbuhan yang berpotensi sebagai antibiotika alami adalah makroalga. Putra (2006) dalam Putri (2016) mengungkapkan bahwa pemanfaatan Makroalga sebagai bahan obat-obatan berhubungan dengan senyawa bioaktif yang terkandung di dalamnya. Menurut Kadi (2004) perairan laut Kepulauan Riau merupakan salah satu tempat tumbuh dari semua jenis makroalga yang ada di Indonesia. Makroalga berpotensi sebagai sumber bahan bioaktif. Hasil studi literatur menunjukkan bahwa 23 jenis makroalga berpotensi sebagai obat, baik sebagai antibakteri, antivirus maupun antijamur, yang meliputi 8 jenis (35\%) dari divisi Rhodophyta, 2 jenis (9\%) dari divisi Chlorophyta, dan 13 jenis (56\%) dari divisi Phaeophyta (Muliani dan Asmanelli, 2011).

Makroalga memiliki kandungan metabolit primer dan sekunder. Kandungan metabolit primer seperti mineral, vitamin, alginat, karaginan, agar dan serat sudah dimanfaatkan sebagai bahan kosmetik untuk pemeliharaan kulit. Selain itu, kandungan metabolit sekunder dari makroalga berpotensi sebagai produser metabolit bioaktif yang dapat digunakan sebagai antibakteri, antivirus, antijamur dan sitotastik (Zainuddin dan Malina, 2009 dalam Siregar, Sabdono dan Pringgenies, 2012). 


\section{METODE PENELITIAN}

Metode penelitian yang digunakan adalah eksperimental laboratoris, data yang didapat dari hasil pengukuran zona bening di sekitar paper disk dianalisa secara deskriptif. Kegiatan yang dilakukan dalam penelitian ini meliputi; sampling makroalga, ekstraksi makroalga, persiapan media biakan bakteri, dan uji resistensi bakteri. Produk pendidikan yang dihasilkan dari penelian ini video pembelajaran dengan materi Bioteknologi untuk kelas XII yang meliputi tiga tahapan, yaitu; tahap perkenalan alat, tahap eksperimen, dan tahap penyajian data hasil esperimen.

Penelitian ini menggunakan dua variabel yaitu variabel terikat adalah $V$. parahemolitycus sedangkan variabel bebas dari penelitian ini adalah makroalga $H$. discoidea, H. dilatata dan D. dichotoma. Penelitian ini dilaksanakan pada 26 Februari sampai dengan 6 April 2018. Pengambilan makroalga dilakukan di perairan Pulau sarang, Kelurahan Sekanak Raya, Kecamatan Belakang Padang, Kota Batam dan keramba jaring apung Balai Budidaya Laut, Batam. Lokasi Pembuatan ekstrak makroalga dan pengujian resistensi bakteri $V$. parahaemolyticus dilakukan di Laboratorium Mikrobiologi Balai Budidaya Laut Batam.

Alat-alat yang digunakan dalam penelitian ini adalah autoclave, inkubator, laminar air flow, inkubator sheker, oven, microwave, timbangan analitik, gelas erlenmeyer, gelas ukur, petri disk diameter $15 \mathrm{~cm}$, botol scot, pinset, pipet mikro, jarum ose, pelubang kertas, gunting, pembakar bunsen, dan penggaris.

Bahan-bahan yang digunakan dalam penelitian ini adalah makroalga $H$. discoidea, $H$. dilatata dan D. dichotoma yang diambil di perairan Pulau Sarang Kecamatan Belakang Padang, Batam. Sampel juga diambil di keramba jaring apung Balai Budidaya Laut, Batam. Bakteri uji yang digunakan adalah bakteri gram negatif $V$. parahaemolyticus HTTC yang berasal dari Balai Budidaya Laut Batam. Etanol sebagai pelarut sampel. Swap kapas, alumunium foil, aquadest, Mueller hinton agar, TCBS agar, TSA, $\mathrm{NaCl}$ 2,5 \%, $\mathrm{NaCl}$ 0,9 \%, media OF (oksidatif/fermentatif), media SIM (Sulfate Indole Motility), Reagen kovac, KOH 3 $\%, \mathrm{H}_{2} \mathrm{O}_{2} 3 \%$, dan kertas oksidase.

Makroalga $H$. discoidea, $H$. dilatata dan $D$. dichotoma diambil di Perairan Pulau Sarang, Kelurahan Sekanak Raya, Kecamatan Sekupang Kota Batam. Sampel yang dibutuhkan sebanyak \pm 200 gram basah setiap jenisnya. Sampel yang sudah diambil dibersihkan dari substratnya dan dicuci hingga bersih menggunakan air laut. Pencucian dilakukan menggunakan air laut bertujuan untuk menjaga zat-zat yang terdapat pada 
makroalga. Sampel yang sudah bersih disimpan di ice box yang berisi es untuk menjaga kesegaran selama perjalanan dari lokasi pengambilan ke lokasi lokasi Eksperimen di Balai Budidaya Laut Batam, Setokok, Kecamatan Bulang, Batam. Sampel yang berasal dari Pulau Sarang Kecamatan Belakang Padang digunakan untuk metode ekstrak basah.

Sterilisasi alat dilakukan untuk menghindari kontaminan mikroorganisme lain yang tidak diinginkan. Semua alat yang akan digunakan baik alat untuk ekstraksi maupun alat untuk inokulasi bakteri disterilkan dalam autoclave dengan suhu $121{ }^{\circ} \mathrm{C}$ dan tekanan $15 \mathrm{lb}$ selama 15 menit. Alat yang berbahan kaca dibungkus dengan aluminium foil sedangkan pinset dan ose disterilisasi dengan cara memijarkannya di atas pembakar bunsen. Petri disk disterilkan menggunakan oven dengan suhu $175^{\circ} \mathrm{C}$ dan dibungkus dengan kertas steril.

Ketiga sampel diekstrak dengan dua metode. Metode pertama adalah metode ekstrak basah yang dibagi menjadi dua konsentrasi ekstrak yang berbeda, ekstrak basah $50 \%$ dan ekstrak basah $100 \%$. Metode kedua adalah metode maserasi dengan pelarut ethanol (perbandingan etanol dan sampel 1:10, w/v). Ekstraksi dengan metode ekstrak basah pada konsentrasi $100 \%$, sampel makroalga $H$. discoidea, $H$. dilatata dan D. dichotoma yang sudah bersih ditimbang sebanyak 25 gr dan ditambahkan aquadest sebanyak $25 \mathrm{ml}$ atau dengan rasio 1:1. Sedangkan untuk ekstrak dengan konsentrasi 50\% sampel diambil sebanyak 25 gr setiap jenisnya dan ditambahkan $50 \mathrm{ml}$ aquadest atau dengan rasio 1:2, w/v. Selanjutnya setiap sampel dimasukkan ke dalam mortal kemudian ditumbuk hingga halus dan homogen. Setelah ekstrak terbentuk, kertas cakram berdiameter $5 \mathrm{~mm}$ direndam dalam larutan sampel selama 120 menit, kemudian diletakkan di atas Mueller Hinton Agar yang telah diolesi bakteri.

Metode maserasi dilakukan dengan cara merendam sampel pada pelarut polar. Ketiga sampel di jemur di bawah panas sinar matahari sampai kering. Sampel kering ditimbang sebanyak 5 gram dan kemudian digunting menjadi bagian-bagian kecil menyerupai serbuk. Sampel dimasukkan ke dalam erlenmeyer dan kemudian ditambahkan $50 \mathrm{ml}$ etanol untuk perendaman. Perbandingan sampel dan etanol $(1: 10 \mathrm{w} / \mathrm{v})$. Perendaman sampel pada etanol dilakukan selama 2 x 24 jam. Selama perendaman erlenmeyer diletakkan pada inkubator shakers dengan kondisi mulut erlenmeyer terbuka, putaran dengan kecepatan $120 \mathrm{rpm}$ dan suhu $45{ }^{0} \mathrm{C}$. Hal ini dilakukan untuk mempercepat kontak antara sampel dan pelarut. Setelah 2 x 24 jam, rendaman sampel dituangkan ke atas cawan petri besar kemudian diuapkan pada suhu ruang selama \pm 30 jam atau sampai etanol mengering. 
Sebelum dilakukan pengujian resistensi bakteri, dilakukan identifikasi terlebih dahulu terhadap bakteri uji untuk memastikan bahwa bakteri uji benar-benar bakteri uji yang diinginkan. Hal ini dilakukan dengan cara melakukan inokulasi bakteri yang telah disediakan di Laboratorium Mikrobiologi BPBL Batam ke dalam Trypticase Soy Agar (TSA) dan diinkubasi selama 24 jam. Setelah itu pengujian identifikasi dilakukan dari bakteri yang sudah berumur 24 jam tersebut (Suherman, et. al., 2016).

Untuk mengetahui tipe dinding sel bakteri, dilakukan uji 3\% $\mathrm{KOH}$. Pereaksi yang digunakan adalah larutan 3\% $\mathrm{KOH}$. Uji $\mathrm{KOH}$ dilakukan dengan cara meneteskan satu tetes larutan 3\% $\mathrm{KOH}$ di atas kaca objek, kemudian dicampurkan dengan biakan bakteri yang sudah diisolasi pada TSA selama 24 jam. Dinding sel bakteri Gram positif resisten terhadap $\mathrm{KOH} 3 \%$, sebaliknya dinding sel bakteri Gram negatif akan larut apabila ditambahkan larutan $\mathrm{KOH} \mathrm{3 \%} \mathrm{sehingga} \mathrm{menunjukkan} \mathrm{perubahan} \mathrm{berupa} \mathrm{terbentuknya} \mathrm{suspensi} \mathrm{bentuk} \mathrm{gel.}$

Uji katalase bertujuan untuk mengetahui kemampuan bakteri delam menghasilkan enzim katalase. Pengujian dilakukan dengan cara mencampurkan setetes $3 \% \mathrm{H}_{2} \mathrm{O}_{2}$ dengan biakan bakteri berumur 24 jam pada gelas objek. Hasil menunjukkan katalase positif apabila dalam suspensi tersebut timbul gelembung gas, dan dinyatakan negatif apabila pada suspensi tidak timbul gelembung gas.

Uji oksidase bertujuan untuk mengetahui kemampuan bakteri dalam menghasilkan enzim sitokrom oksidase. Cara pengujian dilakukan dengan mengoleskan biakan bakteri berumur 24-48 jam pada kertas saring yang mengandung $1 \%$ Tetramethyl-pphenylenediamine dihydrochloride. Hasil dinyatakan positif apabila kertas saring berubah menjadi biru sampai kehitaman dan negatif apabila tidak terjadi perubahan warna.

Uji oksidatif/fermentatif bertujuan untuk mengetahui kemampuan bakteri memproduksi asam dari berbagai jenis karbohidrat secara oksidatif atau fermentatif. Pengujian dilakukan dengan pembiakan bakteri pada media oksidatif (tanpa parafin) dan media fermentatif (media dengan parafin) dengan metode tusuk. Setelah diinkubasi selama 24 jam, bakteri dinyatakan fermentatif (F) apabila kedua media warnanya berubah menjadi kuning, bersifat oksidatif $(\mathrm{O})$ apabila perubahan warna hanya terjadi pada media oksidatif, dan bersifat non oksidatiffermentatif (-) apabila pada kedua media tidak terjadi perubahan warna.

Uji motilitas dilakukan untuk melihat gerakan bakteri. Untuk melakukan pengujian motilitas dapat menggunakan media semi solid (Shulphate Indol Motility) SIM. Pengujian dilakukan dengan cara menusukkan biakan bakteri berumur 24-48 jam dan selanjutnya 
diinkubasi selama 24 jam. Hasil positif apabila terbentuk zona keruh di sekitar tusukan bakteri.

Uji indol dilakukan untuk mengetahui kemampuan bakteri dalam menghasilkan indol. Pengujian indol dapat dilakukan terhadap biakan bakteri pada media yang mengandung asam amino salah satunya media SIM (Shulphate Indol Motility). Pereaksi yang digunakan pada uji indol adalah pereaksi kovac's/erlich. Pengujian dilakukan dengan meneteskan tiga sampai empat tetes pereaksi kovach/erlich pada biakan bakteri umur 24-48 jam. Reaksi positif ditunjukkan dengan terbentuknya rose indol yang ditandai dengan terjadinya cincin/lapisan yang berwarna merah. Sedangkan negatif ditunjukkan dengan tidak adanya perubahan warna.

Media TCBS merupakan media selektif untuk bakteri Vibrio. Pada media TCBS agar, apabila ditemukan koloni berwarna hijau, koloni tersebut diduga sebagai koloni $V$. parahaemolyticus, V. mimicus, V. hollisae, V. damsella dan V. vulnificus. Apabila koloni yang tumbuh berwarna kuning, maka koloni tersebut diduga sebagai $V$. alginolyticus, $V$. fluvialis, V. furnissi, V. metscnokovii dan V. cincinnatiensis.

Sebanyak 10,2 gram bubuk MHA merek marck dimasukkan ke dalam Erlenmeyer, lalu dilarutkan dengan menambahkan $300 \mathrm{ml} \mathrm{NaCl}$ 2,5\% yang sudah disterilkan. Kemudian dipanaskan hingga homogen di dalam microwave. Setelah homogen MHA disterilkan di dalam autoclave dengan suhu $121{ }^{\circ} \mathrm{C}$ selama 15 menit. Setelah MHA steril, MHA dituangkan kedalam 15 petri disk sebanyak $\pm 20 \mathrm{ml}$. Penuangan MHA pada petri disk dilakukan pada laminar air flow.

Biakan bakteri diambil mengunakan ose sebanyak 1 ose, dan kemudian disuspensikan ke dalam larutan $\mathrm{NaCl}$ 0,9\% sebanyak $40 \mathrm{ml}$. Larutkan menggunakan vortex sampai diperoleh kekeruhan yang sesuai dengan standar 0,5 MacFarland atau sebanding dengan jumlah bakteri $10^{8}$ (CFU)/ml. Dengan menggunakan swap kapas steril, swap kapas dicelupkan dalam suspensi biakan bakteri, setelah diperas dengan cara menekan dan memutar swab kapas pada dinding tabung sebanyak dua kali, lalu diusapkan pada Mueller hinton agar dengan cara garis menggaris, rapat dan sejajar, lalu putar 60 derajat dan lakukan garisan serupa sebanyak empat kali, hingga terjadi penyebaran biakan bakteri secara merata ke seluruh permukaan agar. Biakan bakteri pada lempeng agar dibiarkan mengering selama 15 menit (Kumala, 2006).

Uji resistensi bakteri dilakukan terhadap tiga jenis makroalga yaitu makroalga $H$. discoidea, $H$. dilatata dan $D$. dichotoma. Pengujian resistensi dilakukan dengan metode difusi agar atau metode Kirby-Bauer. Paper disk (kertas cakram) yang sudah direndam pada larutan 
ekstrak makroalga diletakkan di atas cawan petri yang telah diusapkan suspensi bakteri Vibrio parahaemolyticus. Biarkan selama 30 menit sampai kertas cakram benar benar menempel pada agar, bungkus lempeng agar menggunakan kertas dan plastik, lalu diinkubasi dengan suhu $30{ }^{\circ} \mathrm{C}$ selama 24 jam.

Diameter zona hambat yang terbentuk karena adanya daya antibakteri dari hasil ekstraksi yang diukur dari sisi sebelah kiri sampai sisi sebelah kanan dengan menggunakan penggaris. Penentuan zona bening dilakukan dengan cara mengamati zona terang (bening) yang berada di bagian terluar kertas cakram. Cara mengukur diameter zona hambat yang terbentuk menggunakan penggaris. Daerah hambatan pertumbuhan bakteri secara umum mengacu pada standar umum antibiotik bila memiliki daerah hambatan $20 \mathrm{~mm}$ atau lebih berarti memiliki kekuatan antibiotik sangat kuat; bila daerah hambatan yang dimilikinya berkisar 10-20 mm berarti kuat; bila daerah hambatan 5-10 mm berarti sedang; bila daerah hambatannya $5 \mathrm{~mm}$ atau kurang dari $5 \mathrm{~mm}$ maka di katakan lemah (Davis dan Stout 1971 dalam Renhoran 2012). Hasil tes kepekaan organisme diklasifikasikan ke dalam dua atau lebih kategori. Sistem yang sderhana menentukan dua kategori, yaitu sensitif dan resisten (Soleha, 2015). Apabila tidak terbentuk zona bening di sekitar kertas saring maka bakteri dinyatakan resisten terhadap antibiotik yang diujikan. Sebaliknya, bakteri dikatakan sensitif terhadap antibiotik apabila adanya zona bening atau zona bebas bakteri yang terbentuk di sekitar kertas cakram. Pengamatan dilakukan selama 1 x 24 jam. Setiap 6 jam zona bening diukur dan dicatat hasilnya.

\section{HASIL DAN PEMBAHASAN}

\section{A. Isolasi dan Identifikasi}

Bakteri $V$. parahaemolyticus yang digunakan dalam uji resistensi berasal dari isolat murni bakteri $V$. Parahaemolyticus ATCC yang merupakan koleksi dari Laboratorium Penyakit Ikan Balai Budidaya Laut Batam. Hasil uji menunjukkan bakteri merupakan gram negatif, uji katalase memberi respon positif, uji Oksidase positif. Hasil uji ini tidak berbada dengan Ramses (2013), bahwa V. parahaemolyticus memberikan reaksi positif terhadap uji citochrom oksidase, motilitas, katalase, membentuk asam/basa pada medium TSI, reduksi nitrat, sitrat, sentifitas $\mathrm{O} / 129 \mathrm{l}$ ug, tumbuh pada $\mathrm{NaCl} 3 \%$ dan 7\%, batang pendek, lysine decarboxylase, ornithin decarboxylase dan memamfaatkan glukosa melalui proses oksidasi- 
fermentasi (OF) pada GMD dan koloni berwarna hijau pada TCBS agar. V. parahaemolyticus memberikan reaksi negative terhadap pengwarnaan Gram, indol, H2S, methyl red, voges proskauer, tidak tumbuh pada $\mathrm{NaCl} 0 \%$ dan $10 \%$ dan arginine dihdrolase. Namun demikian dimungkinkan adanya perbedaan hasil uji karena perbedaan zat kimia yang digunakan dan tidak tertutup kemungkinan disebabkan oleh perbedaan asal isolate (Ramses, 2013).

Uji identifikasi selanjutnya adalah uji oksidatif/fermentatif pada media oksidatif (tanpa parafin) dan media fermentatif (media dengan parafin) dengan metode tusuk. Setelah diinkubasi selama 24 jam, bakteri dinyatakan fermentatif $(F)$ karena kedua media warnanya berubah menjadi kuning. Selanjutnya uji motilitas dengan menggunkan media SIM (Shulphate Indol Motility) dengan metode tusuk. Setelah diinkubasi selama 24 jam bakteri uji dinyatakan memiliki sifat motil karena terbentuk zona keruh di sekitar tusukan bakteri. Uji identifikasi selanjutnya adalah uji indol menggunakan pereaksi kovac. Reaksi positif ditunjukkan dengan terbentuknya rose indol yang ditandai dengan terjadinya cincin/lapisan yang berwarna merah pada media SIM berisi bakteri uji yang sudah diinkubasi selama 24 jam setelah diteteskan pereaksi kovach. Uji identifikasi selanjutnya adalah uji tumbuh pada TCBS agar yang merupakan media selektif bakteri Vibrio sp. Setelah diinkubasi selama 24 jam koloni yang tumbuh pada media TCBS agar berwarna hijau yang menandakan bahwa benar yang diujikan tersebut adalah bakteri Vibrio $s p$.

\section{B. Uji Resistensi Bakteri Vibrio parahaemolyticus terhadap Eksrak Makroalga (Eksrak} basah)

Ekstrak basah merupakan ekstraksi dengan cara menambahkan beberapa ml aquadest ke beberapa gram sampel dengan rasio 1:1 (Tari, 1999) Untuk pembuatan ekstrak dengan konsentrasi $100 \%$ sampel makroalga $H$. discoidea, $H$. dilatata dan $D$. dichotoma yang sudah bersih ditimbang sebanyak $25 \mathrm{gr}$ dan ditambahkan aquadest sebanyak $25 \mathrm{ml}$ atau dengan rasio 1:1. Sedangkan untuk ekstrak dengan konsentrasi 50\% sampel diambil sebanyak 25 gr setiap jenisnya dan ditambahkan $50 \mathrm{ml}$ aquadest atau dengan rasio 1:2 w/v. Selanjutnya setiap sampel dimasukkan ke dalam mortal kemudian ditumbuk hingga halus dan homogen. Penggunaan aquadest dalam ekstraksi basah dikarenakan aquadest merupakan pelarut universal dan tidak mengubah $\mathrm{pH}$ larutan oleh karena sifatnya yang netral (Syahrijuita, et al., 2012)

Berdasarkan hasil pengamatan setiap 6 jam selama 24 jam, tidak ditemukan zona bening di sekitar kertas cakram dengan konsentrasi ekstrak 100\% maupun 50\%. Hal ini dikarenakan 
pelarut yang digunakan dalam ekstraksi makroalga bersifat sangat polar sehingga pelarut tidak mampu menarik keluar zat bioaktif yang terkandung di dalam makroalga. Hal ini dipertegas oleh pendapat Anggitha (2012) dalam Wahyuningtyas, Permana dan Wiadnyani (2017) yang menyatakan Efektivitas ekstraksi suatu senyawa oleh pelarut sangat tergantung kepada kelarutan senyawa tersebut dalam pelarut, sesuai dengan prinsip like dissolve like yaitu suatu senyawa akan terlarut pada pelarut dengan sifat yang sama. Penggunaan jenis pelarut atau kekuatan ion pelarut dapat memberikan pengaruh terhadap rendemen senyawa yang dihasilkan.

Menurut Hardiningtyas (2009), meskipun aquadest mempunyai konstanta dielektrikum paling besar (paling polar) namun penggunaannya sebagai pelarut pengekstrak jarang digunakan karena mempunyai beberapa kelemahan seperti menyebabkan reaksi permentatif (mengakibatkan perusakan bahan aktif lebih cepat), pembengkakan sel dan larutannya mudah terkontaminasi. Titik didih aquadest mencapai $100^{\circ}$ C. Menurut Winarno (2004) dalam Yulianti, Susilo dan Yulianingsih (2014), aquadest (air) berfungsi sebagai bahan yang dapat mendispersikan senyawa yang ada dalam bahan. Yulianti, Susilo dan Yulianingsih (2014) berpendapat bahwa kadar air dapat mempengaruhi sifat-sifat fisik (kekerasan dan kekeringan) dan sifat-sifat fisika-kimia, perubahan-perubahan kimia (pencoklatan enzimatis, kerusakan mikrobiologis, dan perubahan enzimatis). Namun dalam penelitian ini, konsentrasi ekstrak (100\% dan 50\%) tidak menunjukkan perbedaan hasil pada uji resistensi bakteri Vibrio parahaemolyticus, hal ini diduga konsentrasi ekstrak 100\% dengan rasio 1:1 sudah merusak kandungan bioaktif yang terdapat di dalam makrolga.

\section{Uji Resistensi Bakteri Vibrio parahaemolyticus terhadap Eksrak Makroalga (Metode Maserasi)}

Uji resistensi bakteri Vibrio parahaemolyticus dengan metode maserasi menggunakan pelarut etanol. Metode maserasi dilakukan dengan cara menambahkan etanol dengan perbandingan sampel dan etanol $(1: 10 \mathrm{w} / \mathrm{v})$. Perendaman sampel pada etanol dilakukan selama 2 x 24 jam. Selama perendaman botol sampel diletakkan pada inkubator shakers dengan kecepatan $120 \mathrm{rpm}$ dan suhu $45{ }^{\circ} \mathrm{C}$. Rendaman sampel diuapkan di atas cawan petri besar pada suhu ruang selama 30 jam atau sampai etanol mengering. Dengan metode maserasi, semua jenis makroalga yang diujikan menunjukkan efektivitasnya sebagai antibiotika alami, hal ini dibuktikan dengan terbentuknya zona bening di sekitar kertas 
cakram yang sudah direndam ekstrak makroalga. Hasil pengamatan per 6 jam memperlihatkan zona bening di sekitar kertas cakram.

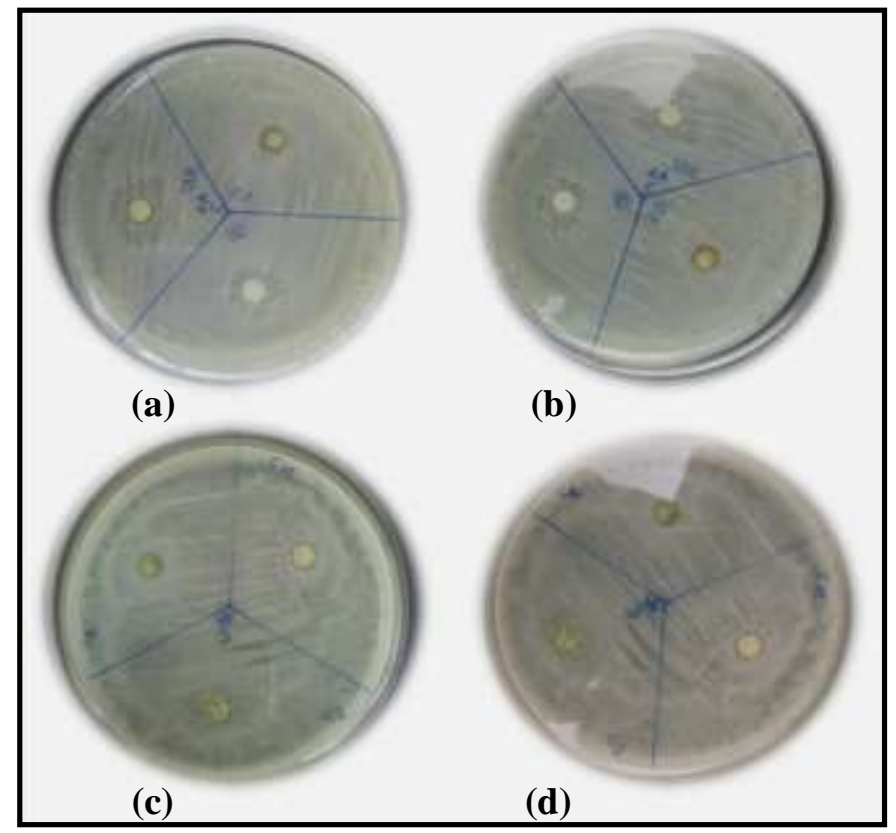

Gambar 1. Penampakan Hasil Uji Resistensi Bakteri Vibrio parahaemolyticus Terhadap Ekstraksi dengan Metode Maserasi Setiap 6 jam. (a) 6 jam. (b) 12 jam. (c) 18 jam. (d) 24 jam.

Selanjutnya pengambilan data dilakukan dengan pengukuran diameter zona bening yang terbentuk di sekitar kertas cakram selama uji resistensi bakteri Vibrio parahaemolyticus pada media mueler hinton agar (MHA). Adapun hasil pengukuran diameter zona bening (mm) setiap sampel setiap 6 jam per ulangan disajikan pada Tabel 1.

Tabel 1. Diameter Zona Bening (mm)

\begin{tabular}{|c|c|c|c|c|c|c|c|c|c|c|c|c|c|c|}
\hline \multirow{4}{*}{ Sampel } & \multicolumn{11}{|c|}{$\begin{array}{l}\text { Diameter Zona Bening (mm) } \\
\text { Per Satuan Waktu (jam) }\end{array}$} & & \multirow{4}{*}{$\begin{array}{c}\text { Jumlah } \\
(\mathbf{m m})\end{array}$} & \multirow{3}{*}{$\begin{array}{c}\text { Rerata } \\
(\mathbf{m m})\end{array}$} \\
\hline & \multicolumn{3}{|c|}{6} & \multicolumn{3}{|c|}{12} & \multicolumn{3}{|c|}{18} & \multicolumn{3}{|c|}{24} & & \\
\hline & & & & & & Ula & $\operatorname{gan}$ & & & & & & & \\
\hline & 1 & 2 & 3 & 1 & 2 & 3 & 1 & 2 & 3 & 1 & 2 & 3 & & \\
\hline H. discoidea & 6 & 6 & 6 & 6 & 7 & 6 & 6 & 7 & 6 & 6 & 7 & 7 & 76 & 6,3 \\
\hline H. dilatata & 6 & 6 & 6 & 6 & 6 & 6 & 6 & 6 & 6 & 6 & 6 & 6 & 72 & 6 \\
\hline D. dichotoma & 6 & 6 & 6 & 6 & 6 & 6 & 7 & 7 & 7 & 7 & 8 & 7 & 79 & 6,6 \\
\hline
\end{tabular}

Ekstraksi dengan metode maserasi efektif mengeluarkan zat bioaktif yang terkandung di dalam makroalga. Hal ini didukung oleh sifat-sifat etanol yang merupakan senyawa polar yang mampu menarik keluar zat bioaktif makroalga. Aziz dan Fresca (2009) menjelaskan bahwa etanol merupakan senyawa organik yang tersusun dari unsur-unsur karbon, hidrogen, dan oksigen. Etanol bersifat miscible terhadap air dan dengan kebanyakan larutan organik, termasuk larutan non-polar seperti aliphatic hydrocarbons. Gugus $\mathrm{OH}$ dalam etanol 
membantu melarutkan molekul polar dan ion-ion dan gugus alkilnya $\mathrm{CH}_{3} \mathrm{CH}_{2}$ - dapat mengikat bahan non-polar. Dengan demikian etanol dapat melarutkan baik non maupun polar. Didukung oleh Sa'adah dan Nurhasnawati (2015), etanol dipertimbangkan sebagai cairan penyari karena lebih efektif, kapang dan kuman sulit tumbuh dalam etanol $20 \%$ ke atas, tidak beracun, netral, absorbsinya baik, etanol dapat bercampur dengan air pada segala perbandingan, panas yang diperlakukan untuk pemekatan lebih sedikit, hal ini berkaitan dengan rendahnya titik didih etanol yaitu $80^{\circ} \mathrm{C}$.

Diameter terbesar yang terbentuk di sekitar kertas cakram adalah 6,6 $\mathrm{mm}$, hal ini dikategorikan lebih kecil dibandingkan penelitian sebelumnya yang dilakukan oleh Natrah, et. al. (2015) Pada makroalga $D$. dichotoma diameter zona bening pada penelitian tersebut mencapai $9 \mathrm{~mm}$. Kecilnya diameter zona bening yang terbentuk dikarenakan singkatnya waktu perendaman kertas saring di dalam ekstrak. Menurut Utami (2009) dalam Kemit, Widarta dan Nocianitri (2017) waktu maserasi yang tepat akan menghasilkan rendemen ekstrak senyawa yang tinggi. Waktu maserasi yang terlalu singkat akan mengakibatkan tidak semua senyawa fitokimia larut dalam pelarut yang digunakan, dan apabila waktu ekstraksi terlalu lama maka senyawa fitokimia yang diekstrak akan rusak. Dua dari tiga makroalga mengalami perluasan diameter $(\mathrm{mm})$ pada masa inkubasi 12 jam hingga 24 jam. Adapun penambahan diameter tersebut terlihat pada Gambar 2.

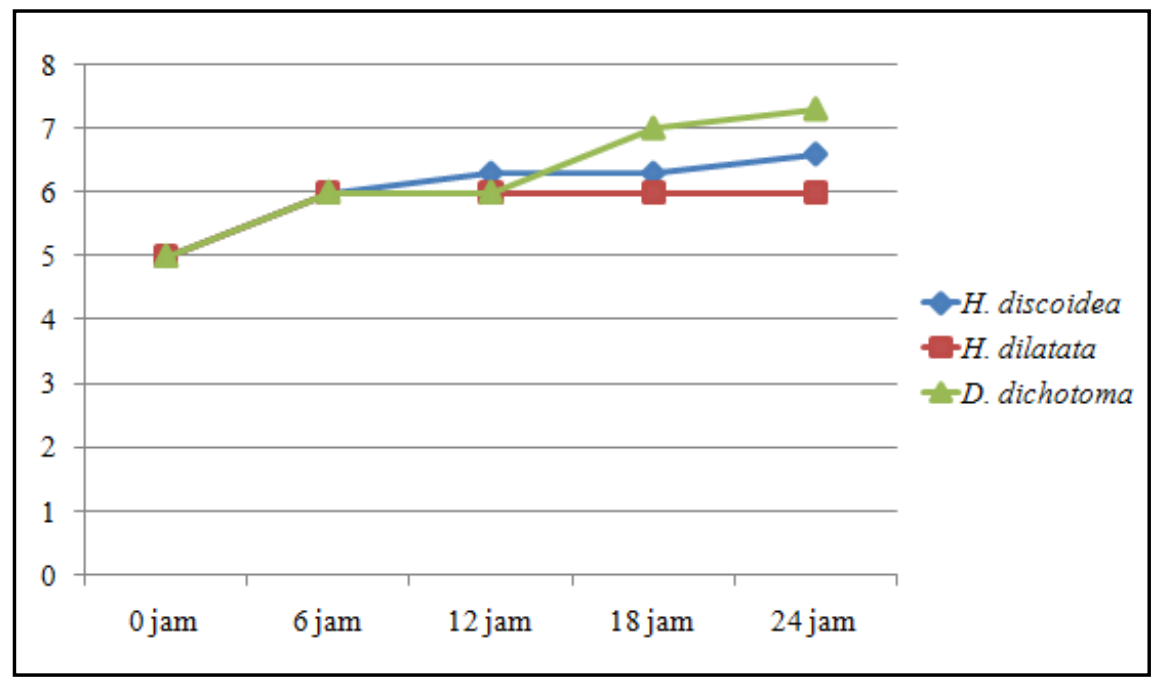

Gambar 2. Rerata Diameter Zona Bening per 6 jam.

Dari Gambar diketahui bahwa diameter zona bening yang terbentuk di sekitar kertas saring sampel makroalga Halimeda discoidea dan Dictyota dichotoma mengalami peningkatan pada masa inkubasi 12 jam hingga 24 jam. Hal ini menunjukkan antibiotik alami 
yang terkandung dalam makroalga Halimeda discoidea dan Dictyota bersifat bakterisida yaitu antibiotik yang mampu membunuh bakteri.

Rerata diameter zona bening $(\mathrm{mm})$ masing-masing makroalga adalah 6,3 $\mathrm{mm}$ untuk maroalga $H$. discoidea, $6 \mathrm{~mm}$ untuk makroalga $H$. dilatata dan 6,6 mm untuk makroalga $D$. dichotoma. Dari angka tersebut dapat ditarik kesimpulan bahwa makroalga $H$. discoidea, $H$. dilatata dan $D$. dichotoma berpotensi sebagai antibiotik alami dengan kategori sedang dengan diamater (mm) 5-10 mm (Davis dan Stout, 1971 dalam Renhoran, 2012). Makroalga yang paling besar membentuk zona bening di sekitar kertas saring adalah makroalga $D$. dichotoma dengan rerata zona bening $6,6 \mathrm{~mm}$.

\section{KESIMPULAN}

Bakteri $V$. parahaemolyticus resisten terhadap antibiotika alami dari ekstrak makroalga H. Discoidea, H. Dilatata dan D. dichotoma yang diekstraksi dengan metode ekstrak basah. Bakteri $V$. parahaemolyticus sensitif terhadap antibiotika alami dari ekstrak makroalga $H$. Discoidea, H. Dilatata dan D. dichotoma yang diekstraksi dengan metode maserasi karena membentuk zona bening di sekitar kertas dengan diameter zona bening ( $\mathrm{mm}$ ) masing-masing makroalga adalah $6,3 \mathrm{~mm}$ untuk maroalga $H$. discoidea, $6 \mathrm{~mm}$ untuk makroalga $H$. dilatata dan 6,6 mm untuk makroalga $D$. dichotoma. Antibiotika alami dari makroalga $H$. discoidea dan $D$. dichotoma bersifat bakterisida (mampu membunuh bakteri), sedangkan dari makroalga $H$. dilatata bersifat bakteristatik (mampu menghambat pertumbuhan bakteri). Zona bening disekitar kertas cakram yang mengandung ekstrak $H$. discoidea, $H$ dilatata dan D. dichotoma memiliki kemamppuan "Sedang” sebagai antibiotik alami yaitu dengan diameter 5-10 mm.

\section{UCAPAN TERIMA KASIH}

Penelitian ini merupakan bagian dari penelitian dosen yang dibiayai institusi Universitas Riau Kepulauan tahun anggaran 2017/2018 dengan nomor kontrak 03/KPPID/LPPM/II/2018.

\section{REFERENSI}

Aziz, T., N, R. C. K., \& Fresca, A. 2009. Pengaruh Pelarut Heksana dan Etanol, Volume Pelarut, dan Waktu Ekstraksi Terhadap Hasil Ekstraksi Minyak Kopi. Teknik Kimia, 16(1), 1-8. 
Hardiningtyas, S. D. 2009. Aktivitas Antibakteri Ekstrak Karang Lunak Sarcophyton sp. yang Difragmentasi dan Tidak Difragmentasi di Perairan Pulau Pramuka, Kepulauan Seribu. (Skripsi), Institut Pertanian Bogor, Bogor.

Kadi, A. 2004. Potensi Rumput Laut di Beberapa Perairan Pantai Indonesia. Oseana, XXIX(4), 25-37.

Kemit, N., Widarta, I. W. R., \& Nocianitri, K. A. 2017. Pengaruh jenis Pelarut dan waktu Maserasi Terhadap Kandungan Senyawa Flavonoid dan Aktivitas Antioksidan Ekstrak Daun Alpukat ( Persea Americana Mill ). ITEPA, V(2), 130-141.

Natrah, F. M. I., Harah, Z. M., Sidik, B. J., Izzatul, N. M. S., \& Syahidah, A. 2015. Antibacterial Activities of Selected Seaweed and Seagrass from Port Dickson Coastal Water against different Aquaculture Pathogens. Sains Malaysiana. 44(9), 1269-1273.

Muliani, \& Asmanelli. 2011. Prosiding Forum Inovasi Teknologi Akuakultur 2011. In Mengenal Biota Alam Penghasil Bakterisida dan Probiotik Untuk Budidaya Perikanan (pp. 621-630).

Putri, S. U. 2016. Efek Ekstrak Makroalga Terhadap Bakteri Staphylococcus aureus dan Methicillin Resisten Staphylococcus aureus. (Skripsi), Universitas Islam Negeri Alauddin, Makassar.

Ramses, 2013. Antagonisme Bakteri Bacillus sp dan Pseudomonas sp Terhadap Bakteri Vibrio parahaemolitycus Patogen Pada Udang Windu (Penaeus monodon fab). Dimensi, Vol. 2(2): 1-14

Renhoran, M. 2012. Aktivitas antioksidan dan antimikroba Sargassum polycystum. (Skripsi). Institut Pertanian Bogor, Bogor.

Sa'adah, H., \& Nurhasnawati, H. 2015. Perbandingan Pelarut Etanol dan Air Pada Pembuatan Ekstrak Umbi Bawang Tiwai ( Eleutherine americana Merr ) Menggunakan Metode Maserasi. Ilmiah Manuntung, 1(2), 149-153.

Syahrijuita, Rahardjo, S. P., Djufri, N. I., \& Djamin, R. 2012. Perbandingan efektivitas beberapa pelarut terhadap serumen obturans secara in vitro di Makassar. ORLI, 42(1), $23-27$.

Suherman., Soraya, S. D., Dinarti., Tusihadi, T., Evan, Y., dan Wibisana, R.I., 2016. Identifikasi Bakteri Patogen pada Ikan. LP2IL, Serang

Tari, D.G.D. 1999. Sensitivitas Bakteri Aeromonas hydrophila Terhadap Tumbuhan Mangrove (Bruguiera gymnorhiza, Rhizophora apikulata, Lumnithzera littorea dan Tumbuhan Perdu. (Skripsi), Universitas Riau, Pekanbaru. 
Wahyuningtyas, S. E. P., Permana, D. G. M., \& Wiadnyani, A. A. I. S. 2017. Pengaruh Jenis Pelarut Terhadap Kandungan Senyawa Kurkumin dan Aktivitas Antioksidan Ekstrak Kunyit ( Curcuma domestica Val.). ITEPA, 6(2).

Yulianti, D., Susilo, B., \& Yulianingsih, R. 2014. Pengaruh Lama Ekstraksi dan Konsentrasi Pelarut Etanol terhadap Sifat Fisika-Kimia Ekstrak Daun Stevia (Stevia Rebaudiana Bertoni M.) Dengan Metode Microwave Assisted Extraction (MAE). Bioproses Komoditas Tropis, 2(1), 35-41. 